VIEWPOINT

Daniel W. Sacks, PhD Department of Business Economics and Public Policy, Kelley School of Business, Indiana University, Bloomington.

$\Psi$

Supplemental content
Corresponding Author: Daniel W. Sacks, PhD, Department of Business Economics and Public Policy, Kelley School of Business, Indiana University, 1309 E 10th St, Bloomington, IN 47405 (dansacks@indiana .edu).

\title{
The Health Insurance Marketplaces
}

Insurers have begun to submit their rate request for 2019 for the Health Insurance Marketplaces, which were created as part of the Patient Protection and Affordable Care Act (ACA). Insurers in Virginia and Maryland are requesting rate increases of as much as $90 \%$, prompting concern that this linchpin of the ACA will not survive. In May 2018, Al Redmer Jr, insurance commissioner of Maryland, stated that "we've been in a death spiral for a year or 2."1 These comments echo a statement from Tennessee insurance commissioner Julie McPeak, who in 2016 expressed concern that the Health Insurance Marketplace was "very near collapse."2

The Marketplaces may not survive if there is a selfsustaining increase in premiums that occurs as healthy people discontinue insurance coverage, thereby driving up average costs of the insured and leading to further premium increases and coverage losses-a so-called death spiral. An example of this phenomenon, but on a smaller scale, is Harvard University's 1995 decision to require its employees to pay higher premiums for its more generous health plan, which was a PPO (preferred provider organization) with more in-network providers. ${ }^{3}$ The plan's enrollment declined by $25 \%$
$2018 .{ }^{4}$ In some states, prices have increased more substantially. In lowa, premiums tripled, and in Tennessee, premiums quadrupled.

Despite these substantial premium increases, enrollment has not changed substantially: from $8.8 \mathrm{mil}-$ lion in 2015 to 8.6 million in 2018, according to open enrollment data from the Centers for Medicare \& Medicaid Services. ${ }^{5}$ In Tennessee, enrollment decreased about 1\%; in lowa, enrollment increased by 8000 covered lives $(\approx 20 \%)$. As shown in the Figure, premiums in every state have increased since 2015 , but in about half of states, enrollment has also increased, and there is no apparent relationship between premium increases and enrollment changes. Overall, enrollment has not declined substantially, so it does not appear that large numbers of healthy people are exiting the Marketplaces, and the concern that self-sustaining premium increases will lead to discontinuation of the Marketplaces is not warranted.

It should not be surprising that enrollment is stable, despite double- or triple-digit premium increases. The premium tax credit in the ACA means that most Marketplace enrollees do not see their premiums increase. The ACA limits how much money a household must spend on health insurance. If actual premiums exceed this limit, the premium tax credit covers the difference. For example, a household with 2 adults, 2 children, and $\$ 100000$ in income may pay as much as $9.66 \%$ of income in premiums, approximately $\$ 805$ per month. If Marketplace premiums were $\$ 800$, this family would receive no subsidy. If premiums were $\$ 855$, the subsidy would be $\$ 50 / \mathrm{mo}$. If premiums were $\$ 1005$, the subsidy would be $\$ 200 / \mathrm{mo}$.

between 1994 and 1995, with young people especially likely to disenroll. The remaining enrollees were higher cost so premiums increased further, and enrollment again decreased in 1996. By 1997, Harvard University concluded that it could not offer the PPO at a reasonable premium and eliminated the plan. The prospect of a similar outcome in the Marketplaces is a major concern because it suggests that absent some policy intervention, current premium increases will continue unabated until nearly everyone ends up with the least generous coverage available or is uninsured entirely.

However, a closer look at the evidence suggests that the Marketplaces are likely to survive. On average, premiums have increased substantially every year since 2016 (eAppendix in the Supplement). Among states using Healthcare.gov, the average premium of a midlevel plan (the silver plan, which covers about 70\% of health care costs) nearly doubled in the last 4 years from about $\$ 220$ per month in 2015 to about $\$ 400$ in
For subsidized households, the subsidy rises dollar-fordollar with the premium. Therefore, despite the large increases in posted premiums, most households do not see any premium increase. Because most Marketplace enrollees do not see their premiums increase, the premium tax credit most likely prevents disenrollment, keeping healthy people covered even as premiums rise.

However, the cost of high premiums must be considered. Higher premium tax credits mean more government spending-with taxpayers ultimately paying the bill. Some households have seen very large premium increases. The premium tax credit is only available to households with income $400 \%$ of the federal poverty line. If that same family of 4 earned $\$ 101000$, its income would be just over this cutoff, and it would receive a subsidy of zero, whether its premium was $\$ 200$ or $\$ 2000$. Unsubsidized households have experienced very large premium increases, but such households are relatively rare. Only about $4 \%$ of nonelderly 
Figure. Across States, Enrollment Changes Are Uncorrelated With Large Changes in Benchmark Premium

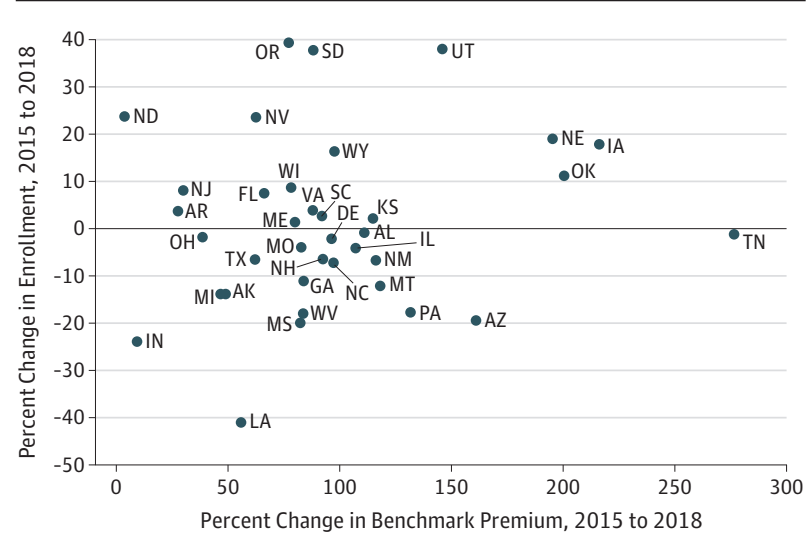

Data are shown for each state using HealthCare.gov for its Marketplace. Enrollment data are from the Centers for Medicare \& Medicaid Services, ${ }^{5}$ and premium data are from HIX Compare. ${ }^{4}$ State-level premiums are the population-weighted average of rating area premiums, with population data estimated from the American Community Survey. ${ }^{6}$

US residents in the 2016 American Community Survey are in households without employer-sponsored insurance and with income greater than $400 \%$ of the poverty line. ${ }^{6}$ Despite the financial costs unsubsidized households face, the design of the premium tax credit likely prevents a substantial adverse selection death spiral in the Health Insurance Marketplaces.
If worsening adverse selection does not explain rising premiums, what does? Only a fraction of the increase can be explained by rising health care prices. From 2012 until 2016, the last year for which data are available, drug and hospital prices have increased by $5 \%$ to $6 \%$ per year, ${ }^{7}$ much slower than the $22 \%$ annual growth rate of Marketplace premiums. The most likely explanation for this rapid premium growth is a volatile policy environment. The ACA contained several transitional provisions. The individual mandate was phased in slowly; its penalty roughly tripled in 2015 and doubled again in 2016. This has likely kept premiums down. However, as the mandate was phased in, 2 premium stabilization programsRisk Corridors and Reinsurance-were phased out. Both of these programs are part of the ACA's transitional provisions, which helped pay for some of the costs of Marketplace insurers. Funding for the Reinsurance program declined by a third in 2016, and both programs ended in 2017. Both programs were meant to help insurers in the early years of the Marketplaces. They were effectively large subsidies, helping pay for the highest-cost enrollees and insurers. It is likely that premiums have increased in their absence. Since 2017, the Trump administration has made several interventions in the insurance market, such as not paying subsidies for insurance plans offering subsidized cost sharing for low-income individuals and setting the individual mandate penalty to zero. These interventions have likely led to further premium increases.

Some have suggested that rising premiums in the last few years show the inherent instability of the ACA Marketplaces. However, that does not appear to be the case. The recent premium increases reflect policy choices, not inherent instability.

\section{ARTICLE INFORMATION}

Published Online: July 9, 2018.

doi:10.1001/jama.2018.8117

Conflict of Interest Disclosures: The author has completed and submitted the ICMJE Form for Disclosure of Potential Conflicts of Interest and none were reported.

\section{REFERENCES}

1. Tozzi J. Obamacare premiums to surge next year, early requests show. Bloomberg. https://www .bloomberg.com/news/articles/2018-05-07 lobamacare-premiums-to-surge-next-year-early -rate-requests-show. May 7, 2018. Accessed May 11, 2018.
2. Fletcher $\mathrm{H}$. Tennessee insurance commissioner: Obamacare exchange "very near collapse."

Tennessean. https://www.tennessean.com/story /money/industries/health-care/2016/08/23 /insurers-get-approval-for-2017-obamacare-rates /89196762/. August 23, 2016. Accessed May 11, 2018

3. Cutler DM, Reber SJ. Paying for health insurance: the trade-off between competition and adverse selection. Q J Econ. 1998;113(2):433-466.

4. Robert Wood Johnson Foundation. HIX Compare. https://hixcompare.org/. Accessed February 2, 2018

5. Centers for Medicare \& Medicaid Services. Open enrollment period public use files. 2015-2018.
https://www.cms.gov/Research-Statistics-Data -and-Systems/Statistics-Trends-and-Reports /Marketplace-Products. Accessed July 3, 2018.

6. Ruggles S, Genadek K, Goeken R, Grover J, Sobek M. Integrated public use microdata series: version 7.0 [dataset]. Minneapolis: IPUMS; 2017. https://international.ipums.org/international/. Accessed January 23, 2018.

7. Health Care Cost Institute. 2016 Health care cost and utilization report. http://www .healthcostinstitute.org/report/2016-health-care -cost-utilization-report//. Accessed May 17, 2018. 